\title{
FORMULATION AND DEVELOPMENT OF EFAVIRENZ TABLETS BY PAPER TECHNIQUE USING
} CO-SOLVENCY METHOD

\author{
CH. DHANA SUBRAHMANYESWARI*, Y. PRASANTH, SAMEEDA RUBEEN
}

Department of Pharmaceutics, School Of Pharmaceutical Science and Technology, JNTU, Kakinada-533001, Andhra Pradesh, India Email: dhanach333@gmail.com

Received: 08 Aug 2019, Revised and Accepted: 10 Oct 2019

\section{ABSTRACT}

Objective: The present study is to formulate and development of efavirenz tablets by paper technique using the co-solvency method, the drug is antiviral drug used for the treatment of HIV.

Methods: In this 7 formulation (F1-F7) were prepared by using different tissue papers like kitchen roll paper, hand kercheif paper, facial tissue paper, with different weights. The prepared tablets were evaluated for hardness, friability, thickness, content uniformity, disintegration time and in vitro dissolution study.

Results: Among all the formulations, F2 (kicthen roll paper with weight $250 \mathrm{mg}$ ) was consired to be the best formulation, which release up to $98.02 \%$ drug in $3 \mathrm{~h}$. The results of stability studies of formulation F2 after a period of 2 mo indicated that the formulation was stable.

Conclusion: It was concluted that a paper tablet of efavirenz shows better results and it does not contain any excipient and increase the dissolution rate.

Keywords: Efavirenz, Tissue paper, Disintegration, In vitro dissolution

(c) 2019 The Authors. Published by Innovare Academic Sciences Pvt Ltd. This is an open access article under the CC BY license (http://creativecommons.org/licenses/by/4.0/) DOI: http://dx.doi.org/10.22159/ijcpr.2019v11i6.36349

\section{INTRODUCTION}

Oral drug delivery is the most efficient drug delivery due to its ease of administration, high stability, more patient compliance, less cost, manufactured easily. So most of the API available in the oral dosage form. As a result, pharmaceutical companies are designed most of the various new oral formulation. Apart from this many waterinsoluble drugs are present class 2 means it as low solubility and high permeability the solubility of the drug increases, the bioavailability of the drug increases [1]. To enhance the solubility of the drug various solubility enhancement technique are like micronization, solid dispersion, conservation, co solvency, etc [2].

\section{Co-solvency [3-5]}

To increase the solubility of non-polar solvent it is mixed with water-miscible or partially miscible solvent popularly known as co solvency technique. It is widely used because it is very simple to prepare and evaluate.

Examples: -ethanol, propylene glycol, PEG 300,

Co-solvent was also used in other techniques like precipitation, $\mathrm{p}^{\mathrm{H}}$ adjustment and solid dispersions. In parenteral low toxic solvents can be used widely like ethanol, propylene glycol, glycerine.

\section{Advantages}

1) It is very simple and accurate.

2) Shows a high degree of solubility when compare to other solubilization techniques.

3) When compare surfactants it has no toxicity problems.

4) It forms simple compounds, not complex compounds.

\section{MATERIALS AND METHODS}

Materials [6, 7]

Efavirenz, various types of papers were used and it contains pharmaceutical quality like kitchen roll paper, facial tissue, handkerchief paper were taken, ethanol.

\section{Method}

Estimation of efavirenz by UV spectrophotometric method [8]

A UV spectrophotometric method based on the measurement of absorbance at $247 \mathrm{~nm}$ in $2 \%$ SLS was used in the present study for the estimation of Efavirenz.

\section{Preparation of standard curve of efavirenz}

In this $10 \mathrm{mg}$ of the drug (efavirenz) was accurately weighed and transferred into $10 \mathrm{ml}$ volumetric flask, dissolved it is in a few $\mathrm{ml}$ of methanol and was made up to $10 \mathrm{ml}$ to get a concentration $1 \mathrm{mg} / \mathrm{ml}$ stock solution. From the stock solution, further dilutions were made with SLS $(2 \% \mathrm{w} / \mathrm{v})$ to get the concentrations ranging from $2.5 \mu \mathrm{g} / \mathrm{ml}$ to $20 \mu \mathrm{g} / \mathrm{ml}$. The absorbance was measured at $247 \mathrm{~nm}$ in UV-Visible Spectrophotometer. The absorbance was plotted against concentrations of drug vs time as shown in fig. 1 . The method obeyed Beer's law in the concentration range of $2.5-20 \mu \mathrm{g} / \mathrm{ml}$.

\section{Sterilization of papers}

Before performing the further steps, sterilization of papers can be done for various grades of papers like (kitchen roll, paper, facial tissue paper, and handkerchief paper) are kept in a hot ir oven at temperature ranges from $150-200^{\circ} \mathrm{C}$ for $10 \mathrm{~min}$ and the sterilized papers were used for further process.

\section{Method for preparation of paper tablet using various papers [9]}

In these sterilized papers are taken with certain parameters like the diameter of $10 \mathrm{~mm}$ and a mass of about $200 \mathrm{mg}$ were produced by using a single punch tablet press. Before compression, the different types of paper were cut into pieces, each possessing a mass of about $200 \mathrm{mg}$. For this, the density of the paper was roughly determined by analysing the height and the respective mass/volume. Based on this the required area of paper was calculated, cut out and weighed to control the mass.

In these various types of tissue, papers were taken up to the $200 \mathrm{mg}$ weight of paper [kitchen roll, disposable Handkerchief, facial tissue]. This paper acts as a matrix. They were cut into $6^{*} 6$ sizes, and then the drug was dissolved ethanol and the solution is dispersed in water. Then the Dissolved drug solution was loaded into the papers 
with pipette drop wise and the dried. The procedure was continued until the required quantity of the drug was loaded into that papers and then again the papers were cut into $1^{*} 1$ sizes and the papers were compressed. The tablet was obtained.

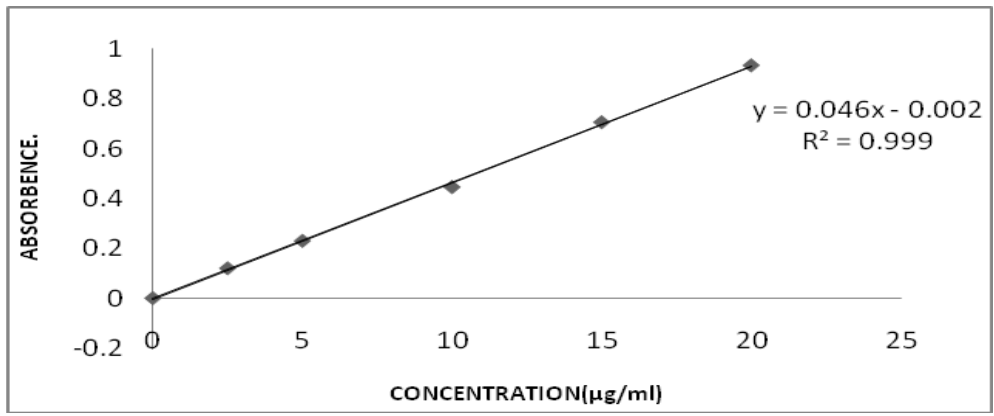

Fig. 1: Calibration curve of efavirenz

Table 2: Interpretation of FTIR spectra of pure drug

\begin{tabular}{|c|c|c|c|c|c|c|c|}
\hline Ingredients & F1 & F2 & F3 & F4 & F5 & F6 & F7 \\
\hline Efavirenz & $50 \mathrm{mg}$ & $50 \mathrm{mg}$ & $50 \mathrm{mg}$ & $50 \mathrm{mg}$ & $50 \mathrm{mg}$ & $50 \mathrm{mg}$ & $50 \mathrm{mg}$ \\
\hline Ethanol & $2 \mathrm{ml}$ & $2 \mathrm{ml}$ & $2 \mathrm{ml}$ & $2 \mathrm{ml}$ & $2 \mathrm{ml}$ & $2 \mathrm{ml}$ & $2 \mathrm{ml}$ \\
\hline Kicthen roll tissue paper & $100 \mathrm{mg}$ & $200 \mathrm{mg}$ & $300 \mathrm{mg}$ & --- & --- & --- & --- \\
\hline Hand kercheif tissue paper & --- & --- & --- & $100 \mathrm{mg}$ & $200 \mathrm{mg}$ & $300 \mathrm{mg}$ & --- \\
\hline Facial tissue paper & --- & --- & --- & --- & --- & --- & $200 \mathrm{mg}$ \\
\hline Total & $150 \mathrm{mg}$ & $250 \mathrm{mg}$ & $350 \mathrm{mg}$ & $150 \mathrm{mg}$ & $250 \mathrm{mg}$ & $350 \mathrm{mg}$ & $250 \mathrm{mg}$ \\
\hline
\end{tabular}

\section{RESULTS AND DISCUSSION}

\section{Drug-paper compatibility studies}

\section{$>\quad$ Fourier transform infrared (FT-IR) studies}

FT-IR spectra of efavirenz and various papers were recorded in the range of 400 to $4,000 \mathrm{~cm}+1$ using a Jasco -FT-IR spectrophotometer (Jasco, Essex, UK) by the KBr disc method. The spectra are shown in fig. 2

\section{Differential scanning calorimetry}

DSC thermograms of pure efavirenz and optimized formulation were recorded on DSC. Samples (15 mg weighed to a precision of $0.1 \mathrm{mg}$ ) were placed in aluminum pans and the lids were crimped using a TA crimper. The thermal behavior of the samples was investigated at a scanning rate of $10^{\circ} / \mathrm{min}$, covering a temperature range of $25-200^{\circ}$ against an empty aluminum pan as reference. The instrument was calibrated with an indium standard. The DSC thermograms.

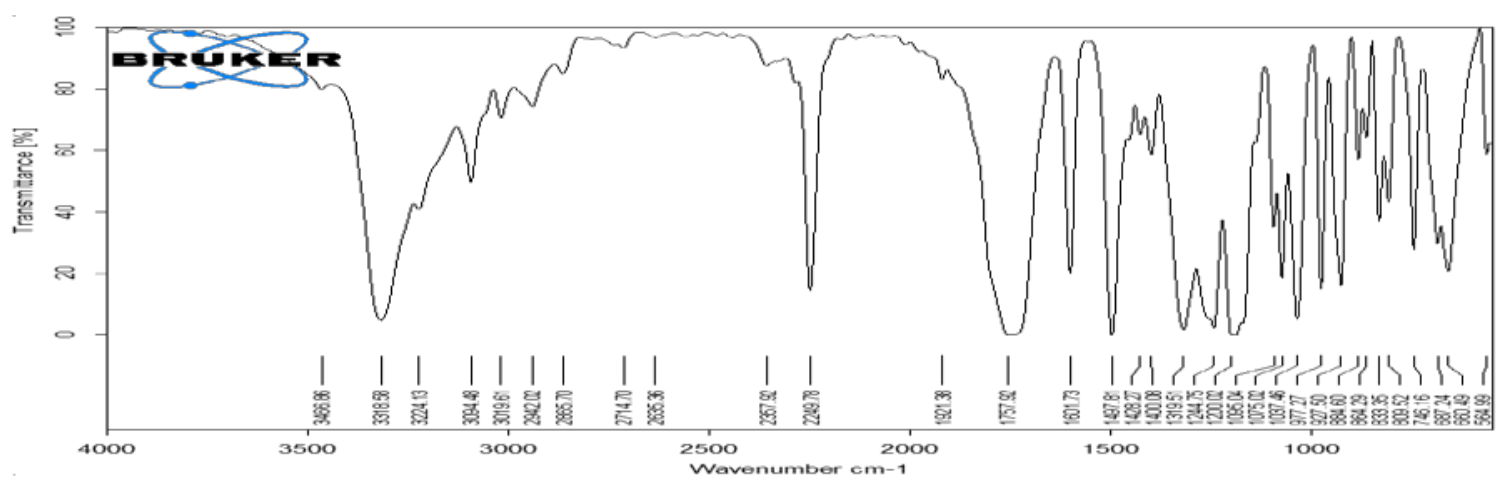

Fig. 2: FITR of pure drug

Table 3: FITR of drug with paper

\begin{tabular}{lll}
\hline S. No. & Wave number $\left(\mathbf{c m}^{-1}\right)$ & Bonds \\
\hline 1. & 1601.73 & $\mathrm{NH}$ \\
2. & 1244.75 & $\mathrm{Cl}$ \\
3. & 1319.51 & $\mathrm{CH}_{3}$ \\
4. & 3318.58 & $\mathrm{OH}$ \\
5. & 1428.27 & $\mathrm{CH}_{2}$ \\
6. & 1200.07 & $\mathrm{CF}_{3}$ \\
S. No. & Bonds \\
1. & 1683.81 & $\mathrm{NH}$ \\
2. & 1244.13 & $\mathrm{Cl}$ \\
3. & 1338.64 & $\mathrm{CH}_{3}$ \\
4. & 3545.38 & $\mathrm{OH}$ \\
5. & 1417.27 & $\mathrm{CH}_{2}$ \\
6. & 1338.38 & $\mathrm{CF}_{3}$ \\
\hline
\end{tabular}




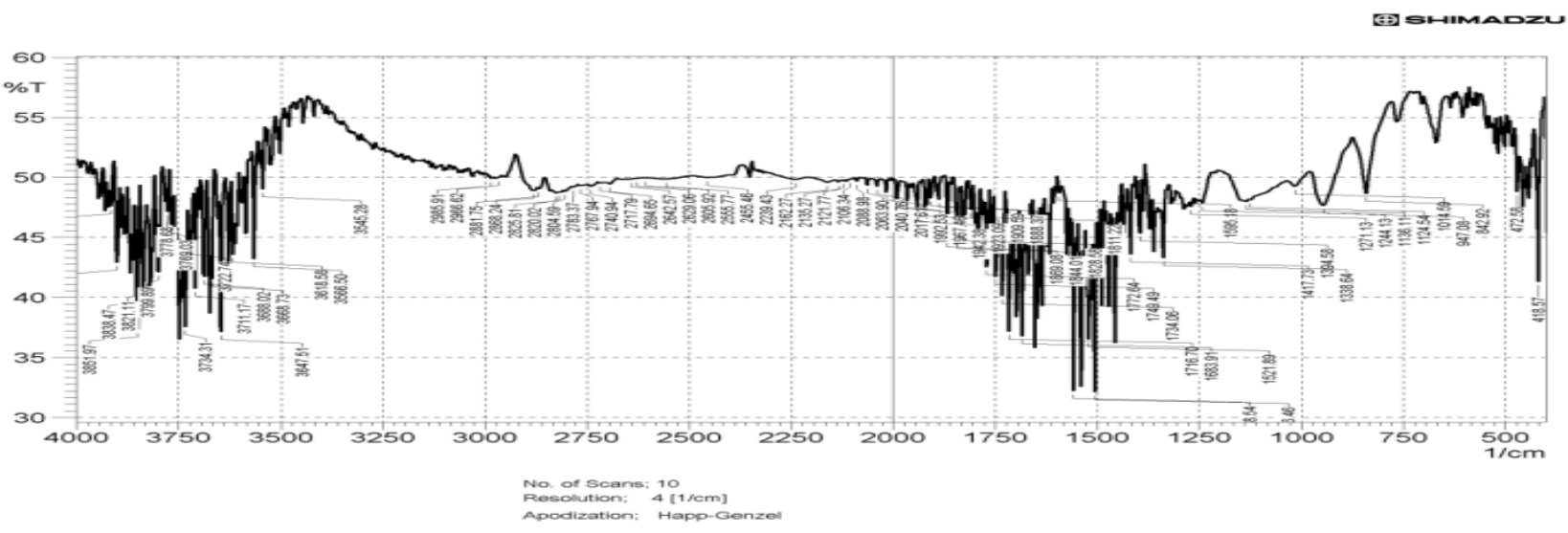

Fig. 3: FITR of drug with paper

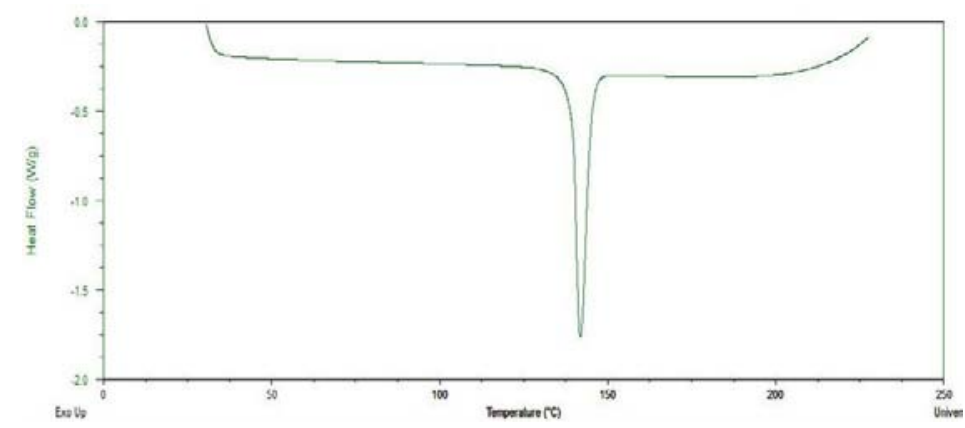

Fig. 4: Thermogram of the efavirenz

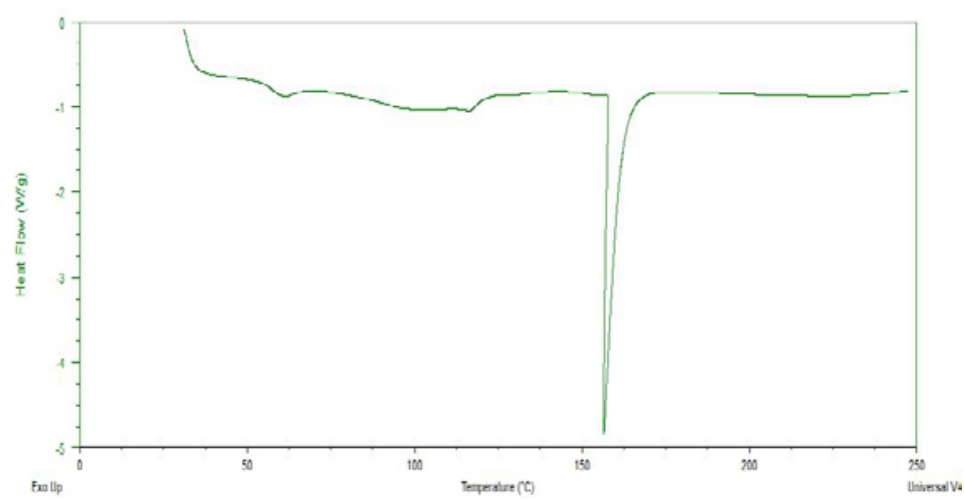

Fig. 5: Thermogram of drug with paper (F2)

\section{Post-compression parameters $[10,11]$}

\section{Hardness}

The tablet Hardness can be determined by using monsanto hardness tester. In this tablet was placed on the lower plunger and reading was adjusted to zero. Then plunger was turned against a spring with force until tablet was fractured and the final reading was noted. Then hardness was by removal from final values with initial values. Then hardness of tablet obtained.

\section{Friability}

The friability of the tablet was determined by roche friability test apparatus. About 20 tablets were selected and check there initial weight. Then they placed in apparatus and rotated for 100 revolutions. Then the tablets were taken and dedusted and check the final weight of the tablets. The percent friability was calculated by the formula.
Friability $=[($ initial weight - final weight $) /$ initial weight $] \times 100$.

\section{Weight variation}

20 tablets were selected randomly and weighed. The average weight of the 20 tablets was calculated. then average weight of the individual tablet should not be more than $10 \%$. Standard deviation and average weight were calculated.

\section{Drug content}

Five tablets from each formulation were randomly selected, accurately weighed, and an average weight per tablet was calculated. Each tablet was cut into small pieces and a known amount of drug that is equivalent to $50 \mathrm{mg}$ of Efavirenz was transferred into a 100-ml volumetric flask $2 \%$ SLS was used to dissolve the drug and solution was made up to the mark. The solution was strained and from which $1 \mathrm{ml}$ was withdrawn into a 
10-ml volumetric flask and diluted with buffer. The resultant solution was determined spectrophotometrically at $247 \mathrm{~nm}$.

\section{Disintegration test}

In this apparatus, six baskets are present the tablet placed on each basket. 2\% SLS buffer is used as the disintegration medium. The temperature of the liquid was maintained at $37^{\circ} \mathrm{c} \pm 2^{\circ} \mathrm{c}$. If 1 or 2 tablets fail to disintegrate completely, repeat the test on 12 additional tablets, not less than 16 of the total of 18 tablets should disintegrate completely

\section{In vitro drug release study}

In this rotating paddle, (USP type 2) apparatus were selected. The dissolution medium contains $900 \mathrm{ml}$ of $2 \%$ SLS buffer. The efavirenz paper tablets were taken. The release study was performed at 37 ${ }^{\circ} \mathrm{C} \pm 0.5{ }^{\circ} \mathrm{C}$ with a rotation speed of $100 \mathrm{rpm}$.

The $5 \mathrm{ml}$ of the sample was withdrawn at a time interval of $2,10,20$, $40,60,90,120,150,180 \mathrm{~min}$ and replaced with $5 \mathrm{ml}$ of dissolution medium the amount of Efavirenz released was determined by UV Spectrophotometer at $247.0 \mathrm{~nm}$.

Table 4: Disintegration time

\begin{tabular}{ll}
\hline Formulation code & Disintegration time (sec) \\
\hline F1 & $80 \mathrm{sec}$ \\
F2 & $60 \mathrm{sec}$ \\
F3 & $112 \mathrm{sec}$ \\
F4 & $150 \mathrm{sec}$ \\
F5 & $70 \mathrm{sec}$ \\
F6 & $180 \mathrm{sec}$ \\
F7 & $160 \mathrm{sec}$ \\
\hline
\end{tabular}

Table 5: Post compression parameters of tablet

\begin{tabular}{|c|c|c|c|c|c|}
\hline Form no. & $\begin{array}{l}\text { Thickness } \\
\text { (mm) }\end{array}$ & $\begin{array}{l}\text { Hardness } \\
\left(\mathrm{kg} / \mathrm{cm}^{2}\right)\end{array}$ & $\begin{array}{l}\text { Friability } \\
(\%)\end{array}$ & $\begin{array}{l}\text { Weight variation } \\
(\%)\end{array}$ & Drug content uniformity \\
\hline F1 & 4.8 & $3.1 \pm 0.21$ & $0.12 \pm 0.031$ & $5.1 \pm 0.12$ & $93 \pm 0.15$ \\
\hline $\mathrm{F} 2$ & 5.5 & $3.2 \pm 0.31$ & $0.22 \pm 0.056$ & $5.6 \pm 0.24$ & $98.7 \pm 0.02$ \\
\hline F3 & 6.0 & $3.8 \pm 0.28$ & $0.28 \pm 0.041$ & $5.9 \pm 0.29$ & $91.2 \pm 0.33$ \\
\hline $\mathrm{F} 4$ & 4.9 & $3.2 \pm 0.22$ & $0.13 \pm 0.32$ & $5.5 \pm 0.11$ & $92.1 \pm 0.12$ \\
\hline F5 & 5.6 & $3.5 \pm 0.11$ & $0.32 \pm 0.12$ & $6.0 \pm 0.31$ & $96.2 \pm 0.09$ \\
\hline F6 & 6.1 & $3.6 \pm 0.31$ & $0.24 \pm 0.19$ & $5.3 \pm 0.57$ & $90.3 \pm 0.31$ \\
\hline F7 & 5.4 & $3.1 \pm 0.25$ & $0.23 \pm 0.25$ & $5.4 \pm 0.32$ & $92.3 \pm 0.25$ \\
\hline
\end{tabular}

Table 6: In vitro dissolution data of efavirenz paper tablet

\begin{tabular}{|c|c|c|c|c|c|c|c|}
\hline \multirow{2}{*}{$\begin{array}{l}\text { Time } \\
\text { (h) }\end{array}$} & \multicolumn{7}{|c|}{ \% Drug release } \\
\hline & F1 & F2 & F3 & F4 & F5 & F6 & F7 \\
\hline 0.5 & $10.71 \pm 0.57$ & $38.12 \pm 0.23$ & $7.29 \pm 0.89$ & $14.32 \pm 0.52$ & $20.31 \pm 1.21$ & $9.28 \pm 1.4$ & $22.31 \pm 0.89$ \\
\hline 1 & $19.13 \pm 0.11$ & $45.31 \pm 0.09$ & $13.12 \pm 1.12$ & $20.32 \pm 3.01$ & $32.88 \pm 0.6$ & $15.32 \pm 3.27$ & $35.89 \pm 0.98$ \\
\hline 1.5 & $32.58 \pm 1.3$ & $64.54 \pm 0.91$ & $26.33 \pm 2.31$ & $31.96 \pm 3.32$ & $54.36 \pm 0.56$ & $27.96 \pm 0.87$ & $48.63 \pm 0.36$ \\
\hline 2 & $45.96 \pm 2.2$ & $74.12 \pm 0.69$ & $38.99 \pm 0.78$ & $47.32 \pm 1.10$ & $69.81 \pm 1.58$ & $37.41 \pm 1.32$ & $59.98 \pm 1.47$ \\
\hline 2.5 & $59.89 \pm 0.32$ & $88.06 \pm 0.21$ & $47.61 \pm 3.21$ & $56.11 \pm 0.99$ & $75.8 \pm 2.65$ & $48.35 \pm 0.65$ & $68.54 \pm 0.96$ \\
\hline 3 & $67.35 \pm 0.09$ & $98.02 \pm 0.03$ & $56.32 \pm 2.98$ & $65.57 \pm 2.11$ & $87.3 \pm 0.97$ & $55.69 \pm 1.98$ & $78.96 \pm 2.98$ \\
\hline 3.5 & $76.11 \pm 0.54$ & ---- & $69.87 \pm 1.69$ & $79.88 \pm 3.50$ & $95.7 \pm 0.11$ & $63.21 \pm 2.9$ & $89.22 \pm 0.21$ \\
\hline 4 & $87.16 \pm 0.78$ & ----- & $79.12 \pm 1.47$ & $91.22 \pm 1.32$ & ---- & $78.96 \pm 3.2$ & $96.13 \pm 0.11$ \\
\hline 4.5 & $95.27 \pm 0.69$ & ----- & $85.21 \pm 0.25$ & $97.34 \pm 0.11$ & ----- & $87.32 \pm 1.2$ & ----- \\
\hline 5 & ---- & ----- & $90.36 \pm 0.36$ & ---- & ----- & $92.11 \pm 0.96$ & ----- \\
\hline
\end{tabular}

Table 7: In vitro dissolution kinetics of efavirenz paper table

\begin{tabular}{|c|c|c|c|c|c|c|}
\hline \multirow[t]{2}{*}{ Formulation code } & \multicolumn{2}{|c|}{ Zero-order } & \multicolumn{2}{|c|}{ First-order } & \multicolumn{2}{|c|}{ Hixson Crowell } \\
\hline & $\mathbf{R}^{2}$ & $\mathbf{K}_{\mathbf{0}}$ & $\mathbf{R}^{2}$ & $\mathbf{K}_{1}$ & $\mathbf{R}^{2}$ & $\mathbf{K}_{\mathbf{H}}$ \\
\hline F1 & 0.919 & 0.821 & 0.854 & 0.011 & 0.923 & 0.01 \\
\hline F2 & 0.992 & 1.25 & 0.940 & 0.016 & 0.972 & 0.023 \\
\hline F3 & 0.896 & 0.562 & 0.872 & 0.009 & 0.897 & 0.015 \\
\hline F4 & 0.956 & 1.01 & 0.925 & 0.010 & 0.948 & 0.019 \\
\hline F5 & 0.984 & 0.654 & 0.964 & 0.015 & 0.948 & 0.007 \\
\hline F6 & 0.876 & 0.747 & 0.864 & 0.007 & 0.823 & 0.012 \\
\hline F7 & 0.965 & 0.99 & 0.957 & 0.012 & 0.954 & 0.018 \\
\hline
\end{tabular}

Table 8: Drug content during stability studies

\begin{tabular}{lll}
\hline \% Drug release (F2) & & \\
\hline Time (weeks) & $\mathbf{3 0}^{\circ} \mathbf{C} / \mathbf{7 0} \mathbf{~ R H}$ & $\mathbf{4 5}{ }^{\circ} \mathbf{C} / \mathbf{7 5 ~ R H ~}^{2}$ \\
\hline $1^{\text {st }}$ week & 99.52 & 99.01 \\
$3^{\text {rd }}$ week & 99.02 & 98.67 \\
$5^{\text {th }}$ week & 98.87 & 98.10 \\
$8^{\text {th }}$ week & 97.53 & 97.00 \\
\hline
\end{tabular}




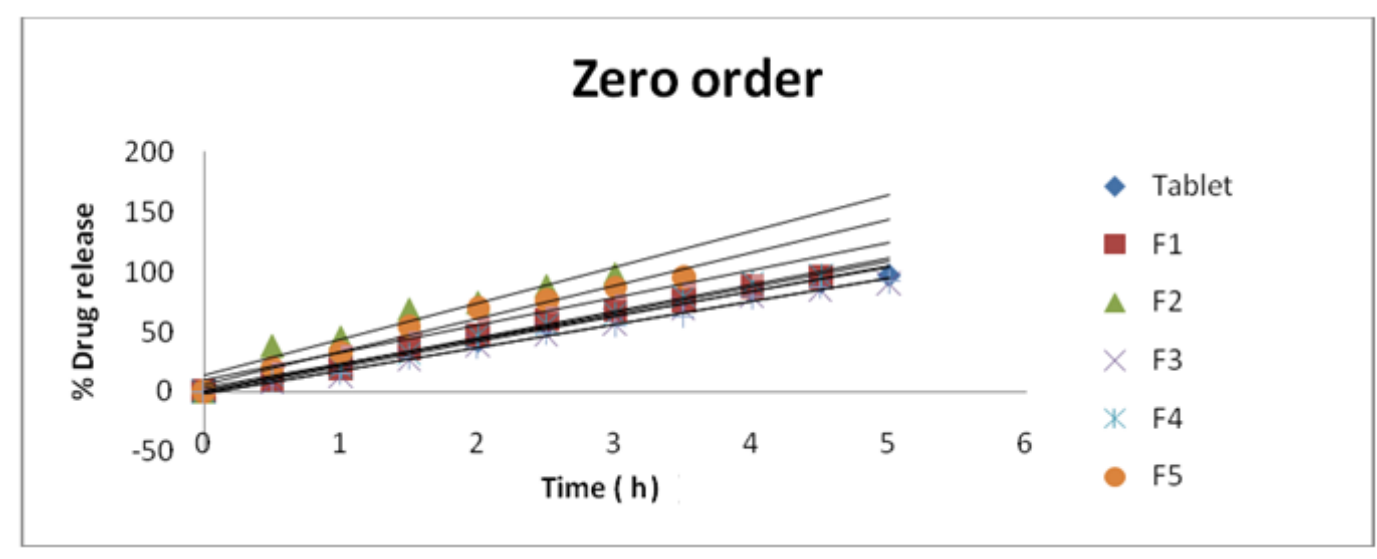

Fig. 6: Zero-order plot

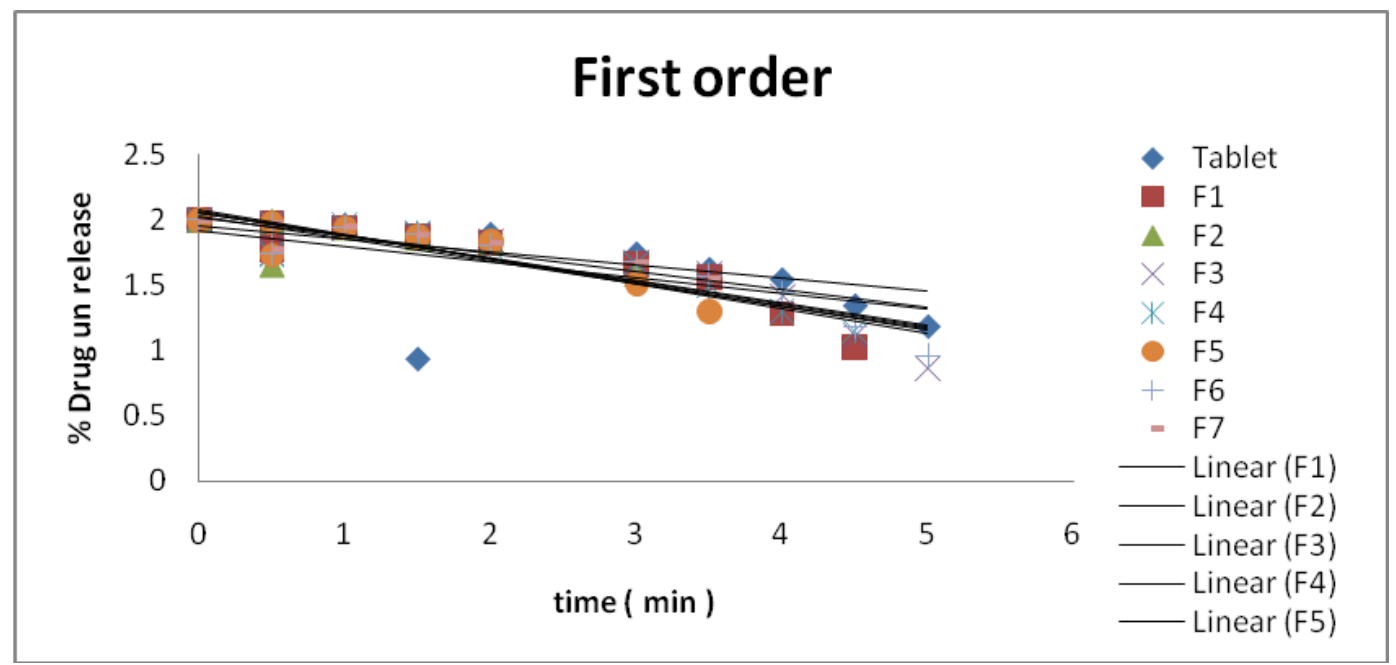

Fig. 7: First order plot

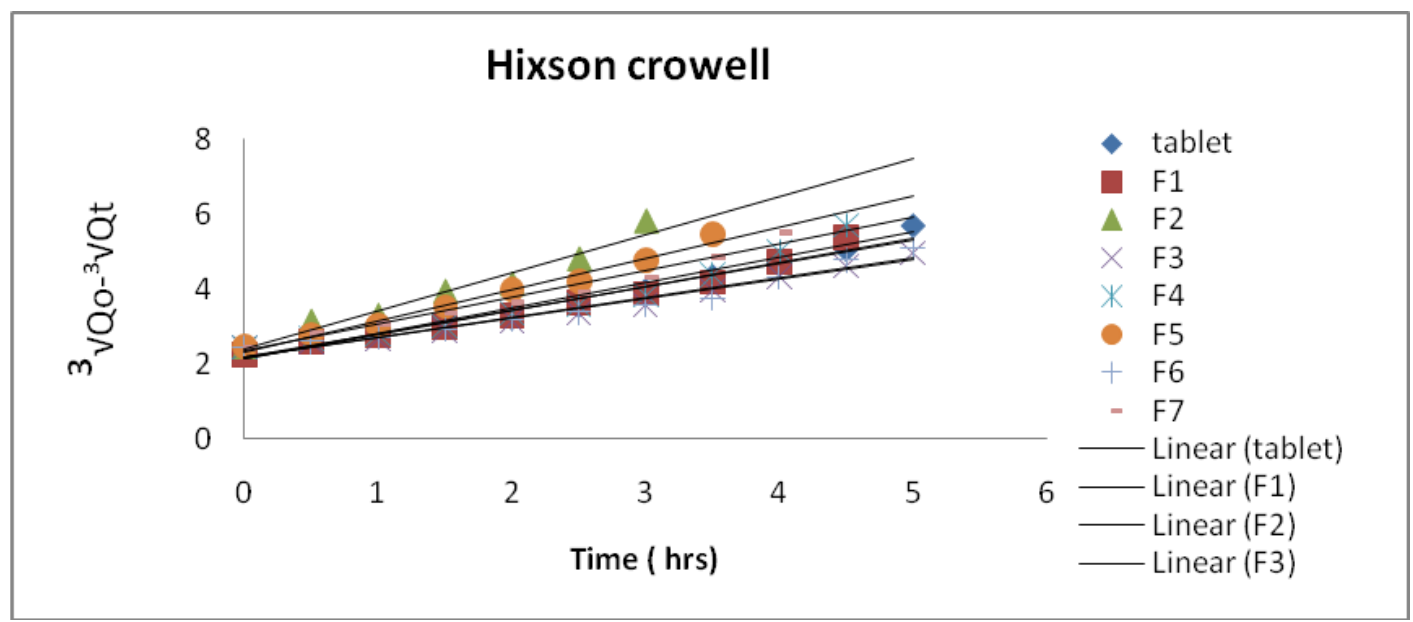

Fig. 8: Hixson crowell

\section{Stability studies}

After storage, changes are not present. The drug content was found to be uniform. The drug release data are shown in indicated that there are no significant changes in the drug release even after storage at $40{ }^{\circ} \mathrm{C}$. The slow drug release characteristics of the product are found to be stable and unaltered.

\section{CONCLUSION}

Efavirenz (EFV), an anti-human immunodeficiency virus (anti-HIV) drug that works by inhibiting the non-nucleoside reverse transcriptase of HIV and is used as a part of the highly active antiretroviral therapy. This drug-related to class 2 which means the drug having low solubility and high permeability. 
The paper tablet has potential advantages it does not contain any excipients and it increases the solubility by cosolvency technique and increases the dissolution and bioavailability of the drug. The paper tablet was prepared by cosolvency technique and incorporated in various papers like kitchen roll, hand Kerchief, facial tissue with various weights are taken and incorporated drug into it. the evaluated results are confirmed that prepared formulation exhibit satisfactory results.

The paper tablet contains efavirenz; among all the formulation F2, shows better release 98.02 for $180 \mathrm{~min}$. From the order of release, it observed that the prepared formulation follows zero-order release kinetics. Other parameters like hardness, friability, weight variation, thickness are also within the limit so the F2 is the optimized formulation. The DSC and FTIR of the pure drug and the papercontaining drug are also conducted. All the parameters are within the limit. The disintegration time of the f2 formulation is $60 \mathrm{sec}$. the stability of the tablet are also attained. So the drug can be released efficiently from the paper and shows its action.

\section{AUTHORS CONTRIBUTIONS}

All the author have contributed equally

\section{CONFLICTS OF INTERESTS}

Authors declare no conflicts of interest

\section{REFERENCES}

1. Ketan T Savjani, Anuradha K Gajjar, Jignasa K Savjani. Drug solubility: importance and enhancement techniques. ISRN Pharm 2012. Doi:10.5402/2012/195727.

2. Poonam Kesarwani, Sameer Rastogi, Vijay Bhalla, Vandana Arora. Solubility enhancement of poorly water-soluble drugs: a review. Int J Pharm Sci Res 2014;5:3123-7.

3. Sikarra Deepshikha, Shukla Vaibhav, Kharia Ankit Anand, Chatterjee DP. techniques for solubility enhancement of poorly soluble drugs: an overview, review article. J Med Pharm Allied Sci 2012;1:18-38.
4. Parve B, Shinde P, Rawat S, Rathod S. Waghmode G. Solubility enhancement techniques: a review. World J Pharm Pharm Sci 2014;3:400-22.

5. Adarsh Kesharwani, Anuradha Kesharwani, Md Amman Maqbool. Solubilization enhancement techniques: an overview. Pharm Chem J 2017;4:121-30.

6. Drug bank open data drug and drug target database. Available from: https://www.drugbank.ca/drugs/DB00625 [Last accessed on 02 Jul 2019].

7. Rowe RC, Sheskey, Owen SC. editor. Handbook of pharmaceutical excipients $5^{\text {th }}$ ed. Uk: PhP Pharmaceutical Press; 2006.

8. Suhas B Gurav, Anant N Deshpande, Jadge Dhanraj, Sandeep D Walsangikar. Spectrophotometric estimation of efavirenz in the formulation and biological fluid. Asian J Biochem Pharm Res 2011;1:402-6.

9. Florian Stumpf, Cornelia M Keck. Tablets made from paper. Available from: https://doi.org/10.1016/j.ijpharm.2018.05.071 [Last accessed on 02 Jul 2019]

10. Leon Lachman, Herbert A Lieberman, Jopesh L Kaing. The theory and practice of industrial pharmacy. 3rd edition; 1987. p. 293, 294, 296, 311-9.

11. Michele Danish, Mary Kathryn Kottke. In: Gilbert Banker, Cristopher T. Rhodes Eds. Modern pharmaceutics. 3rd edition. Marcel Deccker, Inc New-York; 1996.

12. Arendt G, de Nocker D, Von Giesen HJ, Nolting T. Expert opin. Drug Saf 2007;6:147.

13. Gallego L, Barreiro P, del Rio R, Gonzalez De Requena D, Rodriguez-Albarino A, Gonzalez-Lahoz J, Soriano V. Analyzing sleep abnormalities in HIV-infected patients treated with efavirenz. Clin Infect Dis 2004;38:430.

14. Kuritzkes DR, Ribaudo HJ, Squires KE, Koletar SL, Santana J, Riddler SA, et al. Plasma HIV-1 RNA dynamics in antiretroviralnaive subjects receiving either triple-nucleoside or efavirenzcontaining regimens: ACTG A5166s. J Infect Dis 2007; 195:1169-76. 